\title{
Is there evidence of anti-malarial multidrug resistance in Burkina Faso?
}

\author{
Charlotte Rasmussen * (i) and Pascal Ringwald
}

\begin{abstract}
Recently, Gansané and colleagues published an article on inadequate efficacy of two different forms of artemisininbased combination therapy (ACT) in Burkina Faso. The development of Plasmodium falciparum resistance to different ACT partner drugs at levels that could affect the efficacy of two ACT would both be startling and a cause for great concern. In reviewing the available data collected since 2008 on ACT efficacy in Burkina Faso, the analysis shows that the reported efficacy of the tested ACT varies greatly. Most of the studies have considerable methodological deviations and challenges, especially in PCR correction done to distinguish between recrudescence and re-infection, and in the failure to omit re-infections in the calculation of efficacy rates. So far, there is no convincing evidence in the articles reviewed that multidrug resistance has emerged in Burkina Faso. However, the potential consequence of failing ACT means that the results published by Gansané et al. urgently need to be confirmed. Furthermore, articles reporting on efficacy data need to include an examination of the potential consequences of any methodological deviations.
\end{abstract}

Keywords: Malaria drug resistance, Anti-malarial efficacy, Therapeutic efficacy studies, Anti-malarial treatment failures

\section{Background}

Anti-malarial drug resistance is a major challenge for malaria control and elimination. Monitoring drug efficacy is important to detect resistance and adapt national treatment policy. The World Health Organization (WHO) has developed a standard protocol for therapeutic efficacy studies (TES) to facilitate the collection of comparable, high quality data. It is recommended to change the treatment policy if good quality studies detect an efficacy below $90 \%$ for the first-line treatment [1].

The WHO recommends artemisinin-based combination therapy (ACT) for the treatment of uncomplicated Plasmodium falciparum. In the Greater Mekong Subregion, artemisinin partial resistance helped facilitate the selection and spread of resistance of ACT partner drugs, the major factor of ACT failures [1]. Artemisinin partial

\footnotetext{
*Correspondence: rasmussenc@who.int
}

Global Malaria Programme, World Health Organization, Geneva, Switzerland resistance has recently been confirmed in Rwanda with the independent emergence and spread of a Pfkelch13 $\mathrm{R} 561 \mathrm{H}$ mutant. While this appears to have affected the clearance rate, so far it did not affect the efficacy of artemether-lumefantrine (AL) or dihydroartemisininpiperaquine (DP) [2]. Assessing the efficacy of partner drugs is as important as investigating emergence and spread of artemisinin partial resistance.

Recently, Gansané et al. published an article on inadequate efficacy of AL and DP in Burkina Faso [3]. Finding simultaneous high failure rates of two ACT whose partner drugs belong to different chemical families in at least two sites is noteworthy (74.4-91.6\% for AL on day 28 and 83.6-97.2\% for DP on day 42 using Kaplan-Meier analysis). If confirmed, the presence of resistance to both lumefantrine and piperaquine at a prevalence that could cause such high failure rates is alarming.

To assess evidence of ACT efficacy in Burkina Faso, published results and methodologies for TES conducted since 2008 were analysed. This information was extracted from the WHO anti-malarial drug efficacy database 
publicly available through the WHO malaria threat maps (https://apps.who.int/malaria/maps/threats).

\section{Current evidence of ACT efficacy in Burkina Faso}

In addition to data presented by Gansané et al. [3], 15 published articles with efficacy data for five recommended artemisinin-based combinations used alone or in combination with methylene blue or primaquine were identified and reviewed [4-18]. An overview of the data presented in the 15 articles can be found in Table 1. The Table lists the deviations from the standard WHO TES protocol and an assessment of the potential impact that these deviations may have had on the proportion of the study patients recorded to have an adequate clinical and parasitological response (ACPR) to treatment. Where possible, the data are presented in the Table by sites rather than combined across sites. For one multi-country study, the reported data does not allow for an analysis of the efficacy data collected in Burkina Faso only [17]. For another multi-country study, the efficacy data are only available as a combined reported efficacy estimate across sites in different countries and drugs [18].

Overall, the most frequent study deviations observed were the classification of re-infection as ACPR instead of excluding them from the analysis; this could lead to a significant overestimation of the efficacy in studies with high number of re-infections. All the other deviations identified could lead to an underestimation of the efficacy. These include using a PCR correction methodology different to the one currently recommended by the WHO, which requires the use of three markers: $m s p 1$, $m s p 2$ and glurp. Using fewer markers could lead to a lower estimated efficacy as a recrudescence requires that at least one allele on every locus is common in the parasites on day 0 and the day of failure.

The recommended first-line treatments for uncomplicated P. falciparum in Burkina Faso are artesunateamodiaquine (ASAQ), AL or DP. In the articles reviewed, the reported efficacy for ASAQ alone or in combination with primaquine or methylene blue ranges from 63.0 to $98.1 \%$. One of the studies finding lower than $90 \%$ efficacy for ASAQ is a randomized trial in Nouna in 2011. This study assessed ASAQ alone or with methylene blue and reported efficacies of 85.1 and $71.4 \%$, respectively [4]. The endpoints in the study were analysed using an intentto-treat methodology classifying patients vomiting, refusing a second dose, or violating the protocol as early treatment failure. A similar study conducted at the same site in 2016 with ASAQ with primaquine or methylene blue did not find the same high early or late treatment failure rate, reporting a failure rate of less than $5.0 \%$ [5].

The reported efficacy for AL ranges from 66.7 to $100 \%$. Two studies finding less than $90 \%$ efficacy for both
ASAQ and AL were done in Nanoro health district in 2008-2010 and 2010-2012. The studies reported failure rates on day 28 of $10.2-22.2 \%$ for AL and $10.3-15.9 \%$ for ASAQ. These trials were effectiveness trials for which treatment is unsupervised (meaning only the first of 6 doses of AL and the first of 3 doses of ASAQ were supervised by health staff, contrarily to efficacy trials for which all doses are supervised) [10, 11]. Therefore, higher treatment failure rates were expected.

A study performed in Bobo-Dioulasso in 2016 also compared ASAQ and AL, finding high failure rates in the $\mathrm{AL}$ arm but not in the ASAQ arm [9]. As no PCR correction was undertaken it is likely that some reported failures were due to re-infection. The difference of efficacy between ASAQ and AL could be due to the shorter elimination half-life of lumefantrine leading to more re-infections in areas of high transmission.

One of two studies done in Comoé Province found less than $90 \%$ efficacy for AL. The studies were done before and after a large community-based distribution of $\mathrm{AL}$, and showed a statistically non-significant decrease of AL efficacy after the distribution in $2012(86.7 \%, \mathrm{n}=105)$ compared to before in $2009(90.5 \%, \mathrm{n}=105)$. The studies in Comoé used only msp 2 in the PCR correction $[6,7]$.

In addition to the AL and ASAQ studies described above finding low efficacy, a number of studies found higher than $90 \%$ efficacy; however, also in those studies deviations mean that the data need to be interpreted with caution. None of the previous studies with DP or any of the studies with artesunate-mefloquine (ASMQ) or artesunate-pyronaridine (ASPY) found an efficacy lower than $90 \%$.

The recent article published by Gansané et al. [3] reports on studies done in 2017-2018 in three sites (Niangoloko, Nanoro, Gourcy), finding PCR-corrected treatment efficacy of $74.4-91.6 \%$ for AL on day 28, and 83.6-97.2\% for DP on day 42 using Kaplan-Meier analysis. Some aspects of the studies and results are worth noting. Pfplasmepsin2 is a validated marker of piperaquine resistance in the Greater Mekong sub-region, but no correlation was reported between DP failure and Pfplasmepsin2 in the study. The study did not include day 7 lumefantrine blood levels, which in the absence of a validated marker for lumefantrine resistance would be useful to help confirm resistance as cause of AL failures. A $12 \%$ discordance between positive and negative results reported during quality control of the microscopy conducted at the Noguchi Memorial Institute for Medical Research in Ghana is concerning. No further indications were provided in the article on the quality of staining, such as the presence of debris on slides or stain used, which could further increase the percentage of discordance on parasite counting. The WHO recommends 
Table 1 Deviation to WHO protocol and impact on treatment outcome

\begin{tabular}{|c|c|c|c|c|c|c|}
\hline Study setting (Ref) & $\begin{array}{l}\text { Study design } \\
\text { (follow-up) }\end{array}$ & Study pop. (n) & ACT & Reported \% ACPR & $\begin{array}{l}\text { Deviation from } \\
\text { WHO protocol }\end{array}$ & Impact on ACPR \\
\hline \multirow[t]{3}{*}{$\begin{array}{l}\text { Nouna health centre } \\
\text { Aug-Oct } 2011 \text { [4] }\end{array}$} & \multirow[t]{3}{*}{ RCT (28 days) } & \multirow[t]{3}{*}{ 6-59 months (193) } & \multirow[t]{3}{*}{$\begin{array}{l}\text { ASAQ VS ASAQ + } \\
\text { MB }\end{array}$} & \multirow[t]{3}{*}{85.1 vs 71.4} & $\begin{array}{l}\text { mITT analysis, ETF } \\
\text { misclassification }\end{array}$ & Decrease \\
\hline & & & & & $\begin{array}{l}\text { PCR correction with } \\
\text { msp1 and msp2 }\end{array}$ & Decrease \\
\hline & & & & & $\begin{array}{l}\text { Re-infection classi- } \\
\text { fied as ACPR }\end{array}$ & Increase \\
\hline \multirow{3}{*}{$\begin{array}{l}\text { Nouna hospital. Oct- } \\
\text { Nov } 2016 \text { [5] }\end{array}$} & \multirow[t]{3}{*}{ RCT (28 days) } & \multirow[t]{3}{*}{ 6-59 months (100) } & \multirow{3}{*}{$\begin{array}{c}A S A Q+P Q v S \\
A S A Q+M B\end{array}$} & \multirow[t]{3}{*}{95.9 vs 95.7} & ITT analysis & Decrease \\
\hline & & & & & $\begin{array}{l}\text { PCR correction with } \\
m s p 1 \text { and } m s p 2\end{array}$ & Decrease \\
\hline & & & & & $\begin{array}{l}\text { Re-infection classi- } \\
\text { fied as ACPR }\end{array}$ & Increase \\
\hline \multirow{2}{*}{$\begin{array}{l}\text { Tiéfora and Man- } \\
\text { godara health } \\
\text { centres, Comoé } \\
\text { Province. Sep-Dec } \\
2009 \text { [6] }\end{array}$} & \multirow[t]{2}{*}{ Single arm (28 days) } & \multirow[t]{2}{*}{ 6-59 months (105) } & \multirow[t]{2}{*}{$\mathrm{AL}$} & \multirow[t]{2}{*}{90.5} & $\begin{array}{l}\text { PCR correction with } \\
\text { msp2 only }\end{array}$ & Decrease \\
\hline & & & & & $\begin{array}{l}\text { Re-infection classi- } \\
\text { fied as ACPR }\end{array}$ & Increase \\
\hline \multirow{2}{*}{$\begin{array}{l}\text { Tiéfora and Man- } \\
\text { godara health } \\
\text { centres, Comoé } \\
\text { Province. Sep-Dec } \\
2012 \text { [7] }\end{array}$} & \multirow[t]{2}{*}{ Single arm (28 days) } & \multirow[t]{2}{*}{ 6-59 months (105) } & \multirow[t]{2}{*}{$\mathrm{AL}$} & \multirow[t]{2}{*}{86.7} & $\begin{array}{l}\text { PCR correction with } \\
\text { msp2 only }\end{array}$ & Decrease \\
\hline & & & & & $\begin{array}{l}\text { Re-infection classi- } \\
\text { fied as ACPR }\end{array}$ & Increase \\
\hline $\begin{array}{l}\text { Ouagadougou } \\
\text { and Nanoro. } \\
\text { 2012-2014 [8] }\end{array}$ & $\begin{array}{l}\text { Multicentre, multi- } \\
\text { county, single arm } \\
\text { ( } 28 \text { and } 42 \text { days) }\end{array}$ & $\begin{array}{l}>28 \text { days and }<5 \\
\text { kg (20) }\end{array}$ & $\mathrm{AL}$ & $\begin{array}{l}100 \text { day } 28-100 \\
\text { day } 42^{\mathrm{a}}\end{array}$ & $\begin{array}{l}\text { Re-infection classi- } \\
\text { fied as ACPR }\end{array}$ & Increase \\
\hline $\begin{array}{l}\text { Colsama and Sakary } \\
\text { health centres, } \\
\text { Bobo-Dioulasso } \\
\text { Jun-Dec } 2016 \text { [9] }\end{array}$ & RCT (28 days) & $>6$ months (281) & AL vs ASAQ & 85.2 vs 97.0 & No PCR correction & Decrease \\
\hline \multirow{3}{*}{$\begin{array}{l}\text { Nanoro health dis- } \\
\text { trict Sep 2008-Jan } \\
2010 \text { [10] }\end{array}$} & \multirow[t]{3}{*}{$\begin{array}{l}\text { RCT ( } 28 \text { and } 42 \\
\text { days) }\end{array}$} & \multirow[t]{3}{*}{ 6-59 months (340) } & \multirow[t]{3}{*}{ AL vs ASAQ } & \multirow[t]{3}{*}{$\begin{array}{l}89.8 \text { vs } 89.7 \text { - day } 28 \\
66.7 \text { vs } 63.0 \text { day } 42\end{array}$} & $\begin{array}{l}\text { PCR correction with } \\
\text { msp1 and msp2 }\end{array}$ & Decrease \\
\hline & & & & & $\begin{array}{l}\text { Re-infection classi- } \\
\text { fied as ACPR }\end{array}$ & Increase \\
\hline & & & & & $\begin{array}{l}\text { Unsupervised treat- } \\
\text { ment }\end{array}$ & Decease \\
\hline \multirow{3}{*}{$\begin{array}{l}\text { Nanoro health dis- } \\
\text { trict Sep 2010-Oct } \\
2012 \text { [11-13] }\end{array}$} & \multirow[t]{3}{*}{ RCT (28 days) } & \multirow[t]{3}{*}{$>6$ months $(680)$} & \multirow[t]{3}{*}{ AL vs ASAQ } & \multirow[t]{3}{*}{77.8 vs 84.1} & $\begin{array}{l}\text { PCR correction with } \\
m s p 1 \text { and msp2 }\end{array}$ & Decrease \\
\hline & & & & & $\begin{array}{l}\text { Re-infection classi- } \\
\text { fied as ACPR }\end{array}$ & Increase \\
\hline & & & & & $\begin{array}{l}\text { Unsupervised treat- } \\
\text { ment }\end{array}$ & Decease \\
\hline \multirow{2}{*}{$\begin{array}{l}\text { Dafra medical } \\
\text { centre, Bobo- } \\
\text { Dioulasso Dec } \\
\text { 2008-Dec } 2010 \\
\text { [14] }\end{array}$} & \multirow[t]{2}{*}{ RCT (42 days) } & \multirow{2}{*}{$\begin{array}{l}6 \text { months }-15 \text { years } \\
(440)\end{array}$} & AL vs ASAQ & 91.1 vs 98.1 & Longer follow-up & Decrease \\
\hline & & & & & $\begin{array}{l}\text { Re-infection classi- } \\
\text { fied as ACPR }\end{array}$ & Increase \\
\hline & Multicentre, multi- & Pregnant women & AL vs ASAQ vs & 93.2 vs 96.7 vs 92.5 & Longer follow-up & Decrease \\
\hline $\begin{array}{l}\text { trict Jun 2010-Aug } \\
2013 \text { [15] }\end{array}$ & $\begin{array}{l}\text { county, RCT (63 } \\
\text { days) }\end{array}$ & (802) & ASMQ & & $\begin{array}{l}\text { Re-infection classi- } \\
\text { fied as ACPR }\end{array}$ & Increase \\
\hline $\begin{array}{l}\text { Balinghi. Oct 2010- } \\
\text { Oct } 2013 \text { [6] }\end{array}$ & $\begin{array}{l}\text { Multicentre, multi- } \\
\text { county, RCT ( } 63\end{array}$ & 6-59 months (245) & AL vs ASMQ & 95.9 vs 97.6 & $\begin{array}{l}\text { Danger sign classi- } \\
\text { fied ETF at day } 1\end{array}$ & Decrease \\
\hline & days) & & & & Longer follow-up & Decrease \\
\hline & & & & & $\begin{array}{l}\text { Re-infection classi- } \\
\text { fied as ACPR }\end{array}$ & Increase \\
\hline
\end{tabular}


Table 1 (continued)

\begin{tabular}{|c|c|c|c|c|c|c|}
\hline Study setting (Ref) & $\begin{array}{l}\text { Study design } \\
\text { (follow-up) }\end{array}$ & Study pop. (n) & $\mathrm{ACT}$ & Reported \% ACPR & $\begin{array}{l}\text { Deviation from } \\
\text { WHO protocol }\end{array}$ & Impact on ACPR \\
\hline \multirow[t]{3}{*}{$\begin{array}{l}\text { Banfora Oct 2010- } \\
\text { Oct } 2013 \text { [16] }\end{array}$} & \multirow[t]{3}{*}{$\begin{array}{l}\text { Multicentre, multi- } \\
\text { county, RCT (63 } \\
\text { days) }\end{array}$} & \multirow[t]{3}{*}{ 6-59 months (115) } & \multirow[t]{3}{*}{ AL vs ASMQ } & \multirow[t]{3}{*}{94.9 vs 91.2} & $\begin{array}{l}\text { Danger sign classi- } \\
\text { fied ETF at day } 1\end{array}$ & Decrease \\
\hline & & & & & Longer follow-up & Decrease \\
\hline & & & & & $\begin{array}{l}\text { Re-infection classi- } \\
\text { fied as ACPR }\end{array}$ & Increase \\
\hline $\begin{array}{l}\text { Ouagadougou and } \\
\text { Nanoro Nov 2013- } \\
\text { Jun } 2015 \text { [17] }\end{array}$ & $\begin{array}{l}\text { Multicentre, multi- } \\
\text { county, RCT ( } 42 \\
\text { days) }\end{array}$ & 6-12 months (90) & $\begin{array}{l}\text { DP different formu- } \\
\text { lation }\end{array}$ & $98: 3$ vs $100^{b}$ & $\begin{array}{l}\text { Re-infection classi- } \\
\text { fied as ACPR }\end{array}$ & Increase \\
\hline $\begin{array}{l}\text { Bobo Dioulasso and } \\
\text { Banfora-Nian- } \\
\text { goloko Oct 2011- } \\
\text { Feb } 2016[18]\end{array}$ & $\begin{array}{l}\text { Multicentre, multi- } \\
\text { county, RCT ( } 28 \\
\text { and } 42 \text { days) }\end{array}$ & > 6 months (1507) & $\begin{array}{l}\text { AL vs ASAQ vs ASPY } \\
\text { vs DP }\end{array}$ & $\begin{array}{l}>99.5 \text { day } 28 \\
98.6 \text { day } 42^{c}\end{array}$ & $\begin{array}{l}\text { Re-infection classi- } \\
\text { fied ACPR if failure } \\
\text { recorded on last } \\
\text { day of follow-up }\end{array}$ & Increase \\
\hline
\end{tabular}

$R C T$ randomized controlled trial, $A C T$ artemisinin-based combination therapy, $A L$ artemether-lumefantrine, $A S A Q$ artesunate-amodiaquine, $A S P Y$ artesunatepyronaridine, $A S M Q$ artesunate-mefloquine, $D P$ dihydroartemisinin-piperaquine, $A C P R$ adequate clinical and parasitological response, $m / T T$ modified intent-to-treat, ITT intent-to-treat, ETF early treatment failure, $P C R$ polymerase chain reaction, msp merozoite surface protein, P. Plasmodium

${ }^{\text {a }}$ Data from all sites in Burkina Faso and Benin

${ }^{b}$ Data from all sites in Burkina Faso, The Gambia, Democratic Republic of Congo, Mozambique, Tanzania

c Data from all sites in Burkina Faso, Guinea and Mali and for all ACT

that if more than $10 \%$ of a sub-sample has non-concordant outcomes, all study results should be reviewed [19]. DNA detected by PCR on day of failure is not enough to confirm the presence of asexual parasites, as DNA is detectable in blood for a long period of time [20]. Presence of gametocytes can lead to misclassification of a failure as recrudescence. Consequently, gametocytaemia must be detected in case of a high treatment failure rate through more extensive reading of slides taken at day of failure against 1,000 white blood cells (WBC) or 100 high-power fields [21,22]. The absence of amplification of glurp reported in the article at such high level is very rarely observed in other studies $(47.6 \%$ amplified). The data presented in the article do not differentiate between glurp amplification failed and not attempted; actually, glurp amplifications were not attempted for 168 paired samples (Institute Pasteur Paris, pers. comm.). Therefore, the calculated glurp amplification success rate should be closer to $92.3 \%$ for 118 paired samples tested, and less than $35 \%$ of the failures were corrected with the 3 recommended markers. Failure to amplify the 3 markers particularly at day of failure should also trigger quality control of microscopy and confirmation of presence of parasites.

\section{Need for further studies}

The analysis showed inconsistent failure rates with AL and ASAQ and that almost all studies in Burkina Faso had methodological deviations. So far, there is no convincing evidence in the articles reviewed that multidrug resistance has emerged in Burkina Faso, in particular amodiaquine, lumefantrine and piperaquine resistance. The most recent results published by Gansamé et al. [3] urgently need to be confirmed by studies with the recommended monitoring and quality control of slide reading.

The WHO recently released a report highlighting major challenges detected during TES, which can have implications for study outcomes [1]. Quality and quality control of slide reading remain a main challenge in many studies. Using a standard protocol does improve comparability over time and among sites. Conducting quality control monitoring before starting the study, at mid-term and at the end of the study does improve the quality of data. PCR correction of treatment failure to distinguish between re-infection from recrudescence is mandatory during efficacy studies. Effectiveness studies are closer to 'real-life' situations but are not relevant to assess ACT efficacy or anti-malarial drug resistance. Reports on efficacy studies with unexpectedly high treatment failure rates need to include an examination and explanation of the type of failures recorded, in particular the criteria on which early treatment failures were classified. Impact of any potential deviation to standard methodologies should be examined.

\footnotetext{
Abbreviations

ACPR: Adequate clinical and parasitological response; ACT: Artemisinin-based combination therapy; AL: Artemether-lumefantrine; ASAQ: Artesunateamodiaquine; ASMQ: Artesunate-mefloquine; ASPY: Artesunate-pyronaridine; DP: Dihydroartemisinin-piperaquine; PCR: Polymerase chain reaction; TES: Therapeutic efficacy studies; WBC: White blood cells; WHO: World Health Organization.
} 


\section{Acknowledgements \\ Not applicable.}

\section{Authors' contributions}

CR and PR performed the analysis and wrote the manuscript. Both authors read and approved the final manuscript.

\section{Funding}

Not applicable.

\section{Availability of data and materials}

All data analysed during this study are included in this published article.

\section{Declarations}

CR and PR are staff members of the World Health Organization. The authors alone are responsible for the views expressed in this publication that do not necessarily represent the decisions, policy or views of the World Health Organization.

\section{Ethics approval and consent to participate}

Not applicable.

\section{Consent for publication}

Not applicable.

\section{Competing interests}

The authors declare that they have no competing interests.

Received: 15 March 2021 Accepted: 5 July 2021

Published online: 19 July 2021

\section{References}

1. WHO. Report on antimalarial drug efficacy, resistance and response: 10 years of surveillance (2010-2019). Geneva, World Health Organization. 2020. https://www.who.int/publications/i/item/9789240012813.

2. Uwimana A, Legrand $E$, Stokes BH, Ndikumana JM, Warsame M, Umulisa $\mathrm{N}$, et al. Emergence and clonal expansion of in vitro artemisinin-resistant Plasmodium falciparum kelch13 R561 H mutant parasites in Rwanda. Nat Med. 2020;26:1602-8.

3. Gansané A, Moriarty LF, Ménard D, Yerbanga I, Ouedraogo E, Sondo P, et al. Anti-malarial efficacy and resistance monitoring of artemetherlumefantrine and dihydroartemisinin-piperaquine shows inadequate efficacy in children in Burkina Faso, 2017-2018. Malar J. 2021:20:48.

4. Coulibaly B, Pritsch M, Bountogo M, Meissner PE, Nebié E, Klose C, et al. Efficacy and safety of triple combination therapy with artesunate-amodiaquine-methylene blue for falciparum malaria in children: a randomized controlled trial in Burkina Faso. J Infect Dis. 2015;211:689-97.

5. Mendes Jorge M, Ouermi L, Meissner P, Compaoré G, Coulibaly B, Nebie $E$, et al. Safety and efficacy of artesunate-amodiaquine combined with either methylene blue or primaquine in children with falciparum malaria in Burkina Faso: a randomized controlled trial. PLOS ONE. 2019:14:e0222993.

6. Siribié M, Diarra A, Tiono A, Soulama I, Sirima S. Efficacité de l'artémétherluméfantrine dans le traitement du paludisme simple de l'enfant en milieu rural au Burkina Faso en 2009. Bull Soc Path Exot. 2012;105:202-7.

7. Siribié M, Diarra A, Tiono AB, Soulama I, Sirima SB. Effet d'une distribution communautaire à large échelle de l'artéméther-luméfantrine sur son efficacité thérapeutique chez les enfants vivant en milieu rural au Burkina Faso. Bull Soc Pathol Exot. 2015:108:120-3.

8. Tiono AB, Tinto H, Alao MJ, Meremikwu M, Tshefu A, Ogutu B. Increased systemic exposures of artemether and dihydroartemisinin in infants under $5 \mathrm{~kg}$ with uncomplicated Plasmodium falciparum malaria treated with artemether-lumefantrine (Coartem ${ }^{\circledR}$ ). Malar J. 2015:14:157.
9. Zongo I, Compaoré YD, Nikiéma F, Zongo M, Barry N, Somé FA, et al. Efficacy of artemether-lumefantrine and artesunate-amodiaquine as first line therapy of uncomplicated malaria in Burkina Faso, 11 years after policy change. Pan Afr Med J. 2020;35:68.

10. Tinto H, Diallo S, Zongo I, Guiraud I, Valea I, Kazienga A, et al. Effectiveness of artesunate-amodiaquine vs. artemether-lumefantrine for the treatment of uncomplicated falciparum malaria in Nanoro, Burkina Faso: a non-inferiority randomised trial. Trop Med Int Health. 2014;19:469-75.

11. Sondo P, Derra K, Diallo-Nakanabo S, Tarnagda Z, Zampa O, Kazienga $A$, et al. Effectiveness and safety of artemether-lumefantrine versus artesunate-amodiaquine for unsupervised treatment of uncomplicated falciparum malaria in patients of all age groups in Nanoro, Burkina Faso: a randomized open label trial. Malar J. 2015;14:325.

12. Sondo P, Derra K, Nakanabo SD, Tarnagda Z, Kazienga A, Valea I, et al. Comparison of effectiveness of two different artemisinin-based combination therapies in an area with high seasonal transmission of malaria in Burkina Faso. Ann Parasitol. 2017;63:127-31.

13. Sondo P, Derra K, Diallo Nakanabo S, Tarnagda Z, Kazienga A, Zampa O, et al. Artesunate-amodiaquine and artemether-lumefantrine therapies and selection of Pfcrt and Pfmdr1 alleles in Nanoro, Burkina Faso. PLoS ONE. 2016;11:e0151565.

14. Lingani M, Bonkian LN, Yerbanga I, Kazienga A, Valéa I, Sorgho H, et al. In vivo/ex vivo efficacy of artemether-lumefantrine and artesunate-amodiaquine as first-line treatment for uncomplicated falciparum malaria in children: an open label randomized controlled trial in Burkina Faso. Malar J. 2020;19:8.

15. PREGACT Study Group, Pekyi D, Ampromfi AA, Tinto H, Traoré-Coulibaly M, Tahita MC, et al. Four artemisinin-based treatments in African pregnant women with malaria. N Engl J Med. 2016;374:913-27.

16. Sirima SB, Ogutu B, Lusingu JPA, Mtoro A, Mrango Z, Ouedraogo A, et al. Comparison of artesunate-mefloquine and artemether-lumefantrine fixed-dose combinations for treatment of uncomplicated Plasmodium falciparum malaria in children younger than 5 years in sub-Saharan Africa: a randomised, multicentre, phase 4 trial. Lancet Infect Dis. 2016;16:1123-33.

17. Gargano N, Madrid L, Valentini G, D'Alessandro U, Halidou T, Sirima S, et al. Efficacy and tolerability outcomes of a phase II, randomized, open-label, multicenter study of a new water-dispersible pediatric formulation of dihydroartemisinin-piperaquine for the treatment of uncomplicated Plasmodium falciparum malaria in African infants. Antimicrob Agents Chemother. 2017;62:e00596-17.

18. West African Network for Clinical Trials of Antimalarial Drugs (WANECAM) Pyronaridine-artesunate or dihydroartemisinin-piperaquine versus current first-line therapies for repeated treatment of uncomplicated malaria: a randomised, multicentre, open-label, longitudinal, controlled, phase 3b/4 trial. Lancet. 2018:391:1378-90.

19. WHO. Assessment and monitoring of antimalarial drug efficacy for the treatment of uncomplicated falciparum malaria. Geneva, World Health Organization; 2008

20. Kamaliddin C, Joste V, Hubert V, Kendjo E, Argy N, Houze SJ. Evaluation of PCR to monitor Plasmodium falciparum treatment efficacy in a nonendemicity setting. Clin Microbiol. 2019;58:e01080-19.

21. WHO, MMV. Methods and techniques for clinical trials on antimalarial drug efficacy: Genotyping to identify parasite populations. Geneva, World Health Organization. 2008. https://www.who.int/malaria/publications/ atoz/9789241596\%20305/en/

22. Felger I, Snounou G, Hastings I, Moehrle JJ, Beck HP. PCR correction strategies for malaria drug trials: updates and clarifications. Lancet Infect Dis. 2020;20:e20-5.

\section{Publisher's Note}

Springer Nature remains neutral with regard to jurisdictional claims in published maps and institutional affiliations. 